\title{
PENGOBATAN TRADISIONAL (JAMU) DALAM PERAWATAN KESEHATAN IBU NIFAS DAN MENYUSUI DI KABUPATEN TEGAL
}

\author{
Ratih Sakti Prastiwi ${ }^{1}$ \\ e-mail: ratih.sakti@ymail.com \\ ${ }^{1}$ Diploma III Kebidanan Politeknik Harapan Bersama \\ Jalan Mataram No.09 Tegal Telp/Fax (0283)352000
}

\begin{abstract}
Abstrak
Masa nifas merupakan masa pemulihan organ reproduksi wanita yang mana sangat rentan terjadi gangguan pada organ reproduksinya. Masyarakat Jawa meyakini dengan mengkonsumsi jamu selama masa nifas, mampu menjaga dan meningkatkan kesehatan ibu nifas, tidak hanya itu, jamu juga membantu produksi ASI selama ibu menyusui. Masyarakat banyak yang memilih jamu dengan alasan lebih mudah didapat dan ekonomis serta lebih manjur dibandingkan dengan obat modern. Penelitian ini dilaksanakan untuk melihat perilaku ibu dalam mengkonsumsi jamu serta melihat efek jamu pada tubuh ibu nifas. Penelitian ini merupakan penelitian kualitatif dengan pendekatan fenomenologi dengan jumlah informan utama sebanyak 4 informan. Data dikumpulkan melalui wawancara mendalam serta observasi selama informan menjalani masa nifas. Keabsahan data kemudian divalidasi dengan cara triangulasi sumber kepada 4 informan triangulasi. Hasil penelitian menunjukkan seluruh informan mengkonsumsi jamu. Adapun jamu yang dikonsumsi bervariasi, ada yang dikonsumsi dalam bentuk pil ada pula jamu olahan. Jamu yang dikonsumsi merupakan jamu untuk menjaga daya tahan tubuh, meningkatkan produksi ASI serta menjaga badan agar tetap ramping. Terdapat satu informan yang ditemukan memiliki tekanan darah selama mengkonsumsi jamu. Tekanan darah informan naik dapat dikarenakan adanya ketegangan sosial antara ibu dan keluarga yang menyebabkan ketegangan pada titik syaraf tertentu sehingga aliran darah tidak lancar. Berdasakan hasil penelitian tersebut maka dapat disimpulkan jamu memiliki komposisi yang membantu proses pemulihan ibu nifas dan peningkatan produksi ASI.
\end{abstract}

Kata kunci : Nifas, Jamu, Pengobatan Tradisional

\section{Pendahuluan}

Masa nifas merupakan periode dimana terdapat perubahan pada kodisi reproduksinya pasca melahirkan. Wanita akan mengalami perubahan fisiologis dimana uterus mengalami pengerutan kembali menjadi ukuran semula. Untuk mengembalikan kondisinya, masyarakat Indonesia memiliki beberapa tradisi seperti membatasi makanan tertentu maupun mengkonsumsi jamu $^{[1,2,3]}$.

Jamu merupakan bentuk pengobatan tradisional yang diturunkan oleh para leluhur masyarakat. Masyarakat menganggap jamu merupakan pengobatan yang lebih aman dibandingkan dengan pengobatan modern. Penggunaan jamu banyak ditemukan pada masyarakat baik saat dalam masa kehamilan, melahirkan maupun masa nifas ${ }^{4}$. Konsumsi jamu lebih banyak ditemui pada masa nifas dibanding masa kehamilan dan persalinan. Kebanyakan masyarakat mengkonsumsi jamu dengan tujuan untuk membantu melancarkan ASI, mencegah datangnya penyakit, menjaga ketahanan tubuh serta menjaga kecantikan ibu khususnya pada organ kewanitaan $^{[4,5]}$.

Kebiasaan mengkonsumsi jamu banyak ditemukan di masyarakat Jawa. Sebanyak $70 \%-80 \%$ masyarakat sangat bergantung pada jamu sebagai pengobatan tradisional. Hal ini dikarenakan untuk mendapatkan jamu lebih mudah dan lebih ekonomis. Selain itu jamu dapat menurunkan kecemasan atau ketegangan pada ibu nifas ${ }^{4}$. Ketegangan yang sering muncul adalah ketegangan sosial. Ketegangan sosial dapat terjadi apabila salah satu warga masyarakat tidak mengikuti tradisi atau kebiasaan masyarakat yang umumnya timbul cibiran hingga pengkucilan. Apabila ketegangan sosial ditemui pada ibu nifas maka akan mempengaruhi kesehatan ibu selama masa nifas berlangsung. Beberapa dampak ketegangan sosial pada ibu antara lain penurunan produksi ASI, stres, depresi, dan sebagainya $^{[6]}$.

Kabupaten Tegal merupakan salah satu kabupaten di Jawa tengah yang masih 
sangat kental tradisi minum jamu. Dengan dilakukan penelitian perilaku konsumsi jamu oleh ibu nifas, peneliti ingin melihat apa yang mendorong ibu nifas mengkonsumsi jamu dan apa efek yang dirasakan oleh ibu nifas selama mengkonsumsi jamu.

\section{Metode Penelitian}

Penelitian ini menggunakan metode kualitatif dengan pendekatan studi fenomenologi. Peneliti berupaya menggali pengalaman dan opini informan mengenai fenomena konsumsi jamu pada ibu nifas yang tinggal di wilayah Kabupaten Tegal. Kabupaten Tegal merupakan salah satu Kabupaten di Jawa tengah yang masih banyak ditemukan ibu nifas yang menjalankan tradisi/ adat khususnya mengkonsumsi jamu ${ }^{[7,8]}$.

Informan penelitian diambil menggunakan teknik sampling purposive sampling. Peneliti menetapkan kriteria informan seperti ibu yang masih dalam masa nifas, mengkonsumsi jamu selama masa nifas, tinggal di lokasi enelitian selama penelitian berlangsung. Untuk mendapatkan informan yang sesuai dengan kriteria tersebut, peneliti dibantu oleh informan kunci yang merupakan Bidan Puskesmas Kaladawa dan menjabat sebagai Koordinator bidan Kesehatan Ibu dan Anak (KIA). Adapun jumlah informan utama diambil kembali menggunakan teknik sampling snowballing dan didapatkan jumlah informan utama sebanyak 4 informan. Untuk memastikan kebenaran data dari informan utama, maka peneliti mengambil mahasiswa semester IV Program Studi Diploma III Kebidanan Politeknik Harapan Bersama sebagai informan triangulasi. Mahasiswa diambil sebagai informan triangulasi karena pada saat pengumpulan data berlangsung mahasiswa tersebut melakukan pendampingan secara komprehensif kepada informan sejak kehamilan hingga masa nifas berakhir, sehingga mahasiswa tahu kegiatan dan perilaku ibu selama masa nifas berlangsung.

Pengumpulan data dilakukan melalui wawancara mendalam kepada tiap-tiap informan. Peneliti menggunakan instrumen panduan wawancara dan catatan lapangan hasil observasi di lapangan. Data yang diperoleh kemudian dilakukan analisis melalui tahapan reduksi data - penyajian data penarikan kesimpulan. Data yang didapat juga dilakukan pengecekan kebenaran data dengan melakukan triangulasi sumber, yaitu dengan melakukan cross check jawaban informan utama dengan informan triangulasi $^{[9,10]}$.

\section{Hasil dan Pembahasan}

Penelitian ini dilakukan untuk mengetahui faktor-faktor yang mempengaruhi ibu nifas dalam mengkonsumsi jamu, serta melihat efek jamu terhadap kesehatan ibu selama masa nifas. Kabupaten Tegal merupakan salah satu kabupaten di Jawa Tengah yang masih sangat kental tradisi mengkonsumsi jamu sebagai pengobatan tradisional. Tidak terlepas pada ibu hamil, bersalin dan nifas. Jamu mulai dikonsumsi segera setelah bayi lahir. Ibu mendapatkan 3 jenis jamu yang dikonsumsi secara bertahap adapula ibu yang mengkonsumsi satu jenis jamu selama 40 hari.

"kalo disini jamunya diminum 3 kali bu secara bertahap (jeda) kalo nggak salah ibu nifas minum jamu uyup-uyu, terus jamu apa saya lupa kalo ndak salah 4-6 minggu (jeda) nah habis itu ibu nifas dikasih galian singset..." (IK.KS, 2 November 2017)

"disuruh mamake minume 2 kali, pagi sama malem. Gak tau isine apa pokoke wis dicampur-campur lah.." (IU. LL, 2 November 2017)

Arti: diminta ibu untuk minum jamu 2 kali, pagi dan malam. Tidak tahu isinya apa yang jelas sudah dicampur beberapa jamu

"Ngombe jamu (sambil menunjuk) kuwe sing pil, jarene tangga jamu nggo wong bar lairan" (IU. EM, 2 November 2017)

Arti: minum jamu (sambil menunjuk) ini yang pil, kata tetangga jamu untuk setelah melahirkan.

"Ibunya minum jamu bu, dua kalo sehari kalo sekarang sih sudah dikurangi sehari sekali" (IT. FR, 22 November 2017)

Masa nifas merupakan periode dimana terjadi proses pemilihan organ-organ reproduksi seperti uterus, jalan lahir, maupun pemilihan luka perineum ${ }^{[11]}$. Untuk 
membantu proses pemilihan selama masa nifas, masyarakat masih banyak yang percaya pengobatan tradisional. Pengobatan tradisional setiap individu berbeda, hal ini dipengaruhi oleh pengalaman. Alasan dalam penggunaan jamu sebagai pengobatan tradisional sangat beragam, namun umumnya mereka mengkonsumsi jamu sebagai upaya preventif (pencegahan) terjadinya permasalahan kesehatan dikemudian hari. Selain itu dikarenakan jamu berasal dari bahan alami bahkan dapat diolah sendiri tergantung keterampilan turun menurun seorang individu, jamu dipandang lebih aman dan ekonomis. Selain itu alasan masyarakat adalah karena tradisi yang telah berkembang di lingkungannya ${ }^{[12]}$.

Perilaku mengkonsumsi jamu telah dipraktekkan sejak lama dan sudah menjadi tradisi di masyarakat. Hal ini juga ditemukan di Madura, dimana mayoritas wanita di Madura mengkonsumsi jamu baik saat hamil dan setelah bersalin dengan tujuan untuk mempermudah proses persalinan dan menjaga rahim tetap sehat setelah melahirkan ${ }^{[13]}$. Tidak hanya agar menjaga kondisi rahimnya agar tetap sehat, ibu nifas mengkonsumsi jamu juga untuk meningkatkan produksi ASI-nya.

"ora ngarti jamu ne isine apa, jare wong tua sih eben ASI ne lancar, banter dadine bayine ora rewel" (IU. LL, 2 November 2017).

Arti: tidak tahu jamu isinya (komposisi) apa saja, kata orang tua agar ASI lancar jadi bayi tidak akan rewel

"nginung jamu mb, eben ASI ne lancar, awake ya luwih buger. Yen ora ngombe jamu awake laranen kabeh" (IU. ST, 2 November 2017)

Arti: minum jamu mb, agar ASI lancar, badan juga lebih segar. Kalo tidak minum badanya sakit/ pegal semua.

Pernyataan informan tersebut didukung oleh pernyataan informan kunci yang menyebutkan bahwa masyarakat percaya jika tidak mengkonsumsi jamu menyebabkan ASI nya sedikit.

"jamu uyup-uyup buat melancarkan ASI, kebanyak masyarakat kalau ASI nya kurang pasti bilang 'keh, gara-gara ora ngombe jamu sih'.." (IK.KS, 2 November 2017)
Jamu uyup-uyup jika dilihat dari komposisinya, yaitu kencur, kunyit, lempuyang, temu giring, temulawak dan daun katuk memiliki manfaat yang cukup baik bagi tubuh ibu. Kencur dan temu giring bermanfaat untuk menimbulkan rasa tenang, hangat dan segar dalam tubuh. Secara tidak langsung kondisi psikologis ibu menjadi lebih stabil. Dengan kondisi ibu yang tenang maka akan menstimulasi produksi oksitosin yang mana oksitosin merupakan salah satu hormon yang memiliki fungsi merangsang prolactin agar terus memproduksi $\mathrm{ASI}^{14}$. Kunyit merupakan bahan lain yang sering digunakan untuk jamu uyup-uyup. Kunyit mengandung banyak nutrisi yang dibutuhkan ibu nifas seperti curcumin, karbohidrat, protein, vitamin $\mathrm{C}$, kalium, fosfor serta lemak. Lempuyang memberikan manfaat peningkatan nafsu makan, dengan mengkonsumsi ini sangat membantu ibu nifas untuk menjaga nutrisinya. Ibu nifas membutuhkan asupan nutrisi 300-500 kkal lebih banyak atau dalam sehari $>2200 \mathrm{kkal}$. Protein pada lempuyang dapat merangsang peningkatan sekresi air susu, begitupula dengan temulawak dan daun katuk dimana memiliki senyawa laktagogum yang mampu merangsang prolactin untuk memproduksi $\mathrm{ASI}^{[11]}$.

Galian singset merupakan salah satu jamu yang dikonsumsi oleh ibu nifas di kabupaten Tegal. Jamu jenis ini bermanfaat untuk membantu wanita dalam mencocokkan datang bulannya yang tidak teratur selain itu jamu ini dapat membantu kondisi wanita agar ramping, wajah lebih berseri-seri serta memperhalus kulit. Jamu ini banyak sidarankan dan digunakan oleh kaum remaja ${ }^{[15]}$. Salah satu jenis tumbuhan yang digunakan pada ramuan galian singset adalah 'adas'. Adas merupakan jenis tanaman yang banyak dimanfaatkan ibu menyusui dan ibu nifas. Adas mengandung senyawa flavonoid dan coumarins yang merupakan kelompok fitoestrogen yang membantu dalam menstimulasi produksi ASI. Selain itu, adas juga memiliki manfaat sebagai anti-inflamasi dan ant-nyeri. Perlukaan pada rahin akibat lepasnya plasenta maupun luka di perineum jika perawatannua tidak baik maka akan menimbulkan inflamasi dan infeksi. 
Masyarakat tegal percaya dengan mengkonsumsi jamu, ibu nifas dapat mencegah terjadinya infeksi ${ }^{[12]}$.

Beberapa efek yang dirasakan oleh informan setiap kali minum jamu adalah perasaan segar dan nyaman pada tubuh. Namun ada pula yang mengeluhkan setiap kali minum jamu informasi pusing berat. Setelah dilakukan pengecekan tekanan darah ditemukan tekanan darah informan tinggi berkisar 130/90 $\mathrm{mmHh}$ 150/100mmHg. Informan telah melakukan pemeriksaan ke Puskesmas dan dokter menyarankan untuk beristirahat dan mengkonsumsi makanan rendah garam dan dilakukan pengaawasan. Namun tekanan darah tetap tinggi.

"IU. LL setiap hari mengeluh pusing kepala, saya cek tekanan darah namun tekanan darahnya tingi. Ibu sudah berupaya untuk istirahat dan makan rendah garam namun tetap tinggi" (IT. FR, 16 November 2017).

Melihat beberapa jenis jamu yang dikonsumsi ibu salah satu kandungannya adalah flavonoid. Flavonoid memiliki efek hipotensi dengan mekanisme kerjanya menghambat aktifitas ACE serta diuretic. Sehingga temuan tersebut cukup bertentangan. Tenaga kesehatan Puskesmas menyarankan untuk mengurangi konsumsi jamu sehari sekali. Informan mengikuti saran tersebut dan terdapat penurunan tekanan darah ${ }^{[16]}$.

"nginunge sedina sekali pas sore, bisa turu sih ora mumet juga" (IU. LL, 2 November 2017)

Arti: minum sehari sekali saat sore hari, bisa tidur dih tidak pusing juag

"Tekanan darahe sempet turun pas minum jamu nya sehari sekali bu, 120/80 $m m H g "$ (IT. FR, 23 November 2017)

Namun dalam perjalanan diakhir periode masa nifas, informan (IU. LL) mengalami peningkatan tekanan darah kembali. Hasil wawancara didapatkan ibu kembali mengkonsumsi jamu dua kali sehari. Sedangkan informan lain mengkonsumsi jamu tidak menemui keluhan tersebut.

"IU. ST minum sehari tiga kali, tidak ada keluhan selama masa nifas ini, ibu tetap mengkonsumsi jamu dan merasa badannya lebih segar" (IT. LL, 2

November 2017)

Perubahan perilaku IU. LL mengkonsumsi jamu tersebut dikarenakan adanya tekanan dari orang tua. Orang tua menekankan bahwa tradisi di wilayah tinggalnya merngkonsumsi ketiga jenis jamu tersebut dan terbukti tidak ditemui masalah. Adanya tuntutan masyarakay dimana anggota keluarga yang lebih muda harus menghargai orang tua dalam sikap, perilaku maupun perkotaan ${ }^{[17]}$.

Perilaku mengikuti tradisi merupakan bentuk keyakinan yang terbentuk secara turun temurun yang diterima begitu saja tanpa mempermasalahkan kebenarannya. Dampak dari pelanggaran tradisi disuatu masyarakat salah satunya adalah adanya ketegangan sosial ${ }^{[17]}$. Fenomena pada kasus IU. LL tersebut merupakan salah satu bentuk ketegangan sosial. Konflik dalam diri informan menyebabkan psikologis ibu terganggu, informan merasa stress dikarenakan adanya tekanan tersebut. Stress diketahui menimbulkan efek ketegangan pada beberapa titik syaraf dan mengganggu aliran darah. Adanya ketidak lancaran aliran darah tersebut mengakibatkan terjadinya peningkatan tekanan darah ${ }^{[18]}$.

\section{Kesimpulan}

Perilaku konsumsi jamu ibu nifas dipandang dari segi medis tidak membahayakan bagi kesehatan tubuh ibu nifas. Komposisi pada jamu jyang dikonsumsi mengandung beberapa senyawa yang mampu mendukung pemulihan kesehatan ibu seperti dari kencur dan temu giring. Komposisi lain membangun dan merangsan hormon prolaktin dalam peningkatan produksi ASI sehingga dapat menurunkan kecemasan ibu akan kurangnya produksi ASI. Konsumsi jamu tidak semua individu memiliki reaksi yang sama. Adakalanya dampak negatif akan muncul apabila kondisi fisik ibu sedang menurun maupun terdapat kondisi psikologis ibu.

\section{Daftar Pustaka}

[1] Kementerian Kesehatan Republik Indonesia. (2016). Profil Kesehatan Indonesia 2015. Jakarta: Kementerian Kesehatan Republik Indonesia 
[2] Rahayu R dan Sugita. (2015). Pengaruh Jus Nanas Terhadap Kecepatan Penurunan TFU dan Penyembuhan Luka Perinium pada Wanita Post Partum. Jurnal Tumbuhan Obat Indonesia. 8(1): 27-37.

[3] Astuti D. (2016). Hubungan Sosial Budaya dengan Konsumsi Sumber Protein Hewani pada Ibu Nifas di BPS Sumiati Gribig Kudus. Jurnal Ilmu Keperawatan dan Kebidanan. 7(1): 3035

[4] Paryono dan Kurniarum A. (2014). Kebiasaan Konsumsi Jamu untuk Menjaga Kesehatan Tubuh Pada Saat Hamil dan Setelah Melahirkan di Desa Kajoran Klaten Selatan. Jurnal terpadu Ilmu Kesehatan, 391): 64-72

[5] Baequny A, Supriyo, Hadayati S. (2016). Efektivitas Minum Jamu (Ramuan Daun Katuk, Kunyit, Lempuyangan, Asem jawa) terhadap Produksi ASI pada Ibu Nifas. Pena Jurnal Ilmu Pengetahuan dan Teknologi 30(1): 51-58

[6] Utari A, roosita K, Damanik M. (2013). Pengetahuan Gizi, Keluhan Kesehatan Kondisi Psikologis dan Pola Pemberian ASI Ibu Postpartum. Jurnal Gizi dan Pangan: 8(3): 187-192

[7] Murti B. (2013). Desain dan Ukuran Sampel untuk Penelitian Kuantitatif dan Kualitatif di bidang Kesehatan. Yogyakarta: Gadjah Masa University Press

[8] Sulaeman E. (2015). Metode Penelitian Kualitatif dan Campuran dalam Kesehatan Masyarakat. Surakarta: UNS PRESS

[9] Idrus M. (2008). Metode Penelitian Ilmu Sosial: Pendekatan Kualitatif dan Kuantitatif edisi kedua. Jakarta: Erlangga

[10] Miles M, Huberman A. (2014). Analisis Data Kualitatif: Buku Sumber tentang Metode-metode Baru. Jakarta: UI- Press

[11] Kumalasari R, Arimbi D, Ismunandar A. (2014). Pemberian Jamu Uyup-uyup terhadap kelancaran pengeluaran Air Susu Ibu (ASI) pada Ibu Nifas. Prosiding Seminar Nasional dan
Internasional, Semarang 9 Agustus 2014

[12] Shanti R, Jumari, Izzati M. (2014). Studi Etnobotani Pengobatan Tradisional untuk Perawatan Wanita di Masyarakat Keratin Surakarta Hadiningrat. Biosaintifika: Journal of Biology \& Biology Education, 6(2): 6169

[13] Imron A. (2013). Implementasi Kebijakan Kesehatan "LIBAS2+" Sebagai Upaya Menurunkan Angka Kematian Ibu dan Bayi di Kabupaten Sampang. Jurnal Kebijakan Kesehatan Indonesia, 2(3): 107-111

[14] Prabasiwi A, Fikawati S, Syafiq A. 2015. ASI Eksklusif dan Persepsi Ketidakcukupan ASI. Kesmas, 9(3): 282-287

[15] Handayani L, Suharmiati, Sakirno S, Djoerban B, Soegijono KR, Pranata. S. (198). Inventarisasi Jamu Madura uang Dimanfaatkan untuk Pengobatan atau Perawatan Gangguan Kesehatan Berkaitan Dengan Fungsi Reproduksi Wanita. Buletin Penelitian Sistem Kesehatan, 2(1): 40-54

[16] Utami V, Hadisaputro S, Rahayu S. (2016). Pengaruh Ekstrak Ketumbar (Coriandum Sativum) terhadap Perubahan tekanan Darah Tikus Pasca Melahirkan. Jurnal Keperawatan Soedirman, 11(3):174-185

[17] Prastiwi R, Budihastuti UR, Wijaya M. (2016). Phenomenology Study: Factors Associated with the Choice of Unskilled Traditional Birth Attendants in Brebes, Central Java. Journal of Maternal and Child Health, 1(4): 268276

[18] Zunaidi A, Nurhayati S, Prihatin T. (2014). Pengaruh Pijat Refleksi Terhadap tekanan Darah pada Penderita Hipertensi di Klinik Sehat Hasta Terapetika Tugurejo Semarang. Prosiding Konferensi Nasional II PPNI Jawa Tengah 2014 